\title{
LEARNING AND ACCOUNTABILITY: MUTUALLY EXCLUSIVE OR COMPLEMENTARY PURPOSES OF EVALUATION OF PUBLIC POLICY INTERVENSIONS
}

\begin{abstract}
Organisations which receive external funding have been strongly influenced by the call to increase accountability, from one hand, and desire to enhance organisational learning on the other. It has been traditionally argued that tensions and trade-offs between these two are inevitable. However, this article demonstrates that it should not necessarily be the case. By reviewing how accountability and organisational learning is defined, and taking account of the recent advancements in evaluation theory and practice, the article explores the ways in which accountability and learning purposes can be reconciled in one evaluation endeavour. It links different types of accountability with different types (loops) of learning. The main argument put forward is that in today's complex and dynamic environment with many unexpected twists of events being caused by multiple variables a broader view of accountability coupled with higher level of organisational learning is needed. This is especially true in reference to innovative public interventions aimed at multidimensional social problems such as sustainable development or poverty alleviation.
\end{abstract}

Keywords: evaluation, accountability, performance measurement, organisational learning, developmental evaluation

\section{Streszczenie}

\section{Uczenie się a rozliczanie odpowiedzialności — wzajemnie wykluczające się czy uzupełniające cele ewaluacji interwencji publicznych}

Organizacje, które finansowane są ze źródeł zewnętrznych, odczuwają silną presję wynikającą z jednej strony ze zwiększania ich rozliczalności (accountability) ze efekty realizowanych przez nie działań, z drugiej - z dążenia do pogłębiania procesów organizacyjnego uczenia się. Pokutuje przekonanie, że napięcia i niezbędne kompromisy między nimi są nieuniknione. Tym niemniej, niniejszy artykuł ma na celu ukazanie, że taki sposób myślenia nie do końca jest 
uprawniony. Na podstawie przeglądu, jak pojęcie rozliczalności (accountability) oraz organizacyjnego uczenia się jest definiowane, a także biorąc pod uwagę najnowsze postępy w teorii i praktyce ewaluacyjnej, artykuł bada sposoby, które pozwalają pogodzić mechanizmy rozliczalności i procesy uczenia się w jednym przedsięwzięciu ewaluacyjnym. Łączy on różne typy rozliczalności z różnymi typami (pętlami) uczenia się. W konkluzji sformułowany został postulat, iż w dzisiejszym złożonym i dynamicznym środowisku, obfitującym w wiele nieoczekiwanych zwrotów akcji, u których podstaw leży wiele zmiennych, niezbędne jest szersze ujęcie rozliczalności pozwalające na wyższy poziom organizacyjnego uczenia się. Jest to szczególnie istotne w odniesieniu do innowacyjnych interwencji publicznych, ukierunkowanych na rozwiązywanie wielowymiarowych problemów społecznych takich jak rozwój zrównoważony czy zwalczanie ubóstwa.

Słowa kluczowe: ewaluacja, wzmacnianie odpowiedzialności, pomiar wyników, organizacyjne uczenie się, ewaluacja rozwojowa

\section{Introduction}

There are various purposes which evaluation can serve. However, learning and accountability are the two central ones. Evaluation can provide an evidence base to demonstrate effects of a particular programme, project or a policy to key stakeholders, be it - donors or general public. It can also serve as a vital learning tool for improving public policies and programmes by supporting more informed decision-making. Organisations which receive external funding have been strongly influenced by the calls to increase accountability, from one hand, and desire to enhance organisational learning on the other. It has been traditionally argued that tensions and trade-offs between these two are inevitable. However, this article demonstrates that it should not necessarily be the case. By reviewing how accountability and organisational learning is defined, and taking account of the recent advancements in evaluation theory and practice (a call for taking a systemic perspective in evaluation research, employment of new evaluation approaches to tackle complex situations, involving non-linear change processes with feedback loops and intertwined influencing factors [Cabrera et al., 2008; Regeer et al., 2016], the article explores the ways in which accountability and learning purposes can be reconciled.

The paper is organised in four sections. Following an introduction, section two discusses the dominant view of the accountability purpose of evaluation and why accountability and learning are frequently kept apart in evaluation practice. Third part pertains to evaluation as a mechanism of organisational learning and links different types of accountability (upwards, downward/horizontal and internal) with different types (loops) of learning. The final one places these considerations against the backdrop of the recent developments in evaluation theory and practice to challenge, as Ebrahim [2005: 56] describes it aptly, "myopic view of accountability" in evaluation processes. 


\section{A tug-of-war between accountability and learning}

As Bovens, Goodin and Schillemans [2014: 1] put it: "Accountability is the buzzword of modern governance". The term is used so often that it seems to have lost its meaning. It occurs parallel with the call for more transparency in public spending in the context of public management reforms at the national as well as supranational level (e.g. European Union). However, regardless of the rising prominence of the term in public discourse, academic scholarship in the field is fragmented and non-cumulative. There are different conceptualisations of the term and different frames set for studying accountability across various disciplines as well as within the same academic discipline.

With regard to the traditional meaning of accountability that is historically rooted in the practice of record-keeping and the discipline of accounting, accountability and learning purposes of a single evaluation endeavour is hardly to be reconciled. This static and mechanical approach to accountability means that evaluation is performed in order to check whether resources were used according to the plan and whether expected effects are achieved and fits squarely into the prevailing system of management, which has been characterised by Senge [2012: 12] in his insightful book Fifth Discipline by the following features: management by measurement (focusing on short-term metrics and devaluing intangibles), compliance-based cultures (getting ahead by pleasing the boss, suppressing conflict), right answers and wrong answers (technical problem solving), managing outcomes versus "designing" systems (fragmentation), uniformity (diversity is a problem to be solved), predictability and controllability (to manage is to control, the "holy trinity of management": planning, organizing, controlling), as well as excessive competitiveness and distrust.

Traditional approaches to evaluation favour this classical modelling approach, which is about prediction and control gained through the specification and measurement of fidelity of implementation and attainment of predetermined outcomes. The underlying presumption is that public policy-makers can foresee in advance what outcomes should be targeted and how to achieve them. There is no acceptance of a departure from the initially developed plan. However, the problem is that adherence to the implementation plan does not guarantee the attainment of predetermined outcomes, since the impact of an public intervention is always the combined result of an intervention and its context, which is beyond our control and is changing over time. Moreover, against this background, no emerging opportunities can be targeted or sized, despite the fact that they can improve the chance of arriving at the desired outcome. As Patton [2017] rightly points out this is not how high performance organisations perceive either development or accountability. Relying on deliberate strategic planning has become insufficient in today's world. However, regardless of its limitations, this approach is suited when the problem is well recognised, there are clear boundaries and limited alterative solutions, one of which is likely to be optimal [Gamble, 2008; Patton, 2017]. 
Guijt [2010: 279-280] argues that accountability and learning is kept apart in evaluation practice due to the deeply rooted conviction that accountability has nothing to do with learning; demonstrating success using hard data of large populations of beneficiaries are more impressive than "telling a more nuanced story about social change, involving contextual difficulties, messy partnerships and intangible but essential outcomes". Many managers assume that there is more order and hence predictability in the world than actually exist, and one-fits-all remedy is feasible. However, understanding the context in which one operates is crucial as different contexts call for different kinds of responses. The Cynefin framework by Snowden and Boone [2007] is a tool which can help to decide how to act in situations with different degrees of complexity. It sorts out the issues faced by decision-makers into five contexts where cause and effect links are more or less clear and reliable. The "simple" and "complicated" domains are regarded as being "ordered" and this is where accountability can be perceived as an external control or monitoring device (accountability as compliance-checking). "Simple" domain is characterised by stability and cause and effect links which are generally obvious. In the "complicated" domain, there are more elements to be analysed, over time, so the cause and effects relationships are not so clear and direct, however, with the expert knowledge they can be identified and predicted in advance with some degree of confidence. This cannot be done in the "complex" and "chaotic" domains which are categorised as "unordered". In the "complex" domain cause and effects links can be deducted only in retrospect and cannot be repeated because the context is in constant flux. The only way to handle complex domain problems is to probe first, then sense, and then to respond. Instead of imposing a concrete course of action, it is more appropriate to allow the path forward to reveal itself and discover manageable patters. (However, in the "chaotic" domain even this is beyond the realms of possibility. Cause and effects links are impossible to determine and manageable patterns do not exist, only turbulence).

In these contexts, accountability must be approached differently, namely accounts for the dynamics. Moreover, it must be born in mind that accountability is a relational concept and that various types of accountability relationships exist, not only towards funders, patrons or policy-makers (upwards accountability), but also other actors somehow affected by public interventions: clients, target populations, communities, etc. (downwards accountability), to colleagues and partners (horizontal accountability), and even it is said that organisations are held accountable to themselves - their own mission (internal accountability) [Ebrahim, 2005; Regeer et al., 2016; for a broader discussion on new forms of accountability see: Brandsen et al., 2011].

However, it must be admitted that in some situations it might be appropriate to conduct evaluation more focused on the accountability perspective and situations when it might be better to focus more on learning perspective, depending on the expectations about evaluation (table 1). 
Table 1

Accountability perspective versus learning perspective

\begin{tabular}{|l|l|}
\hline \multicolumn{1}{|c|}{ Accountability perspective } & \multicolumn{1}{c|}{ Learning perspective } \\
\hline The main question: What works? & $\begin{array}{l}\text { The main question: What works for whom and } \\
\text { under what conditions? }\end{array}$ \\
\hline $\begin{array}{l}\text { Typically reflects the average impact of an } \\
\text { intervention (limited usefulness of that evidence } \\
\text { for decision makers in other settings) }\end{array}$ & $\begin{array}{l}\text { Provides insights how to implement a given } \\
\text { intervention in different settings }\end{array}$ \\
\hline Quantitative research prevails & Qualitative research prevails \\
\hline Objectivity & Subjectivity is unavoidable* \\
\hline
\end{tabular}

* Swanborn in 1999 nicely illustrated the difference between quantitative research and qualitative research as "counting coffee beans" versus "tasting the coffee", since every restaurateur is aware that "how coffee tastes" is determined not only by the number and quality of the beans, but also several inherently subjective factors [cited in: Van der Knaap, 2004: 31].

Source: own elaboration.

\section{Linking accountability and learning}

When it is acknowledged that "accountability is about providing answers for your behaviour", which is a point of departure in defining accountability in public administration literature [Bovens et al., 2014: 5], the concept of accountability appears not to be so at odds with learning.

Organisational learning is "the process of improving actions through better knowledge and understanding" [Fiol, Lyles, 1985: 803]. Thus, tackles two issues: acquiring new knowledge (exploration) as well as the use of knowledge possessed to cause behavioural change (exploitation). Evaluation can contribute to uncovering causal mechanisms of an intervention, to better understanding the nature of social problems and processes, and the knowledge obtained, in turn, to the improvement of on-going and future public interventions in a specific area. As some authors rightly point out [Fiol, Lyles, 1985; Ebrahim, 2005; Olejniczak et al., 2012] organisational learning is something more than a simple adaptation since it must be preceded by reflection on observed effects, their interpretation, understanding the phenomena and processes taking place and their processing by the organization. Thus, the result of learning is change. Depending on the depth of the introduced changes, single and double loop learning can be distinguished [Argyris, Schön, 1996]. The former one represents a situation in which modus operandi within the adopted intervention model is corrected, the operative level. It revolves around the question: Are we doing the things right? In the double learning loop, the assumptions that underpin a specific public intervention are questioned, thus affecting the strategic choices. The fundamental question of the evaluation is: Are we doing the right things? This is characteristic for the theory-based evaluation, which is frequently referred to as "opening the black box" of an intervention [Stame, 2004]. It concentrates on identifying the mechanism of change-determining why and 
how the intervention results in specific effects. On the top of that, one more level of learning can be distinguished: deutero learning, which involves changes in the way we learn. Balcerak [2006] points out that this concept can be understood in a threefold way: as acquisition of lower and higher level learning skills, as metalearning, that is, reflection and control over one's learning process and as an institutionalization of the organizational learning process. Patton [2017] calls it the third loop learning, indicating that the process of learning how to learn is embedded in the model of developmental evaluation.

As it has been mentioned, there are different types of accountability relationships. Various actors (funders, beneficiaries etc.), usually have somewhat different expectations from the evaluation of a particular project, programme, what, in turn, implies different evaluative questions (the focus of evaluation is on different issues). Hence, it can be argued that different types of accountability imply a different type (loop) of learning (table 1). Upwards accountability (to founders, governing bodies, reflects a vertical principal-agent relationship) usually implies a focus on (using the words of Najam [1996: 345; cited in: Ebrahim, 2005: 60]: "spending of designated moneys for designated purposes"); preference is given to short-term, tangible effects of an initiative under evaluation (performance measurement). This type of accountability can be linked to a single loop learning, since it concentrates on what have been done (actions), the effective execution of a given project, programme. (Though, when evaluation is carried out to legitimize a decision that has already been made prior to the commissioning of the evaluation (the symbolic use of evaluation), no learning occurs). However, recently one can observe a shift of attention from measuring merely outputs of a given initiative (direct and immediate effects of a programme, e.g. a medical equipment purchased thanks to the programme) towards measuring outcomes (differences made by the outputs, e.g. improvements in health care). This can enable also double-loop learning, in particular when casual links between inputs and outcomes are properly established.

Double-loop learning more frequently occurs in the case of downwards accountability as those affected by a public initiative are interested whether a given programme in fact leads to a solution of a particular problem. Hence, evaluation in this case revolves around the question: Are we doing the right things? This may challenge the underlying assumptions of a given programme, initiative. Unintended effects of a programme under evaluation, their persistency are not neglected. A call for more participatory approaches to evaluation can be heard to draw on local knowledge, ideas and innovation (e.g. Engel, Carlsson, 2002; Lennie, Tacchi, 2014].

Finally, inward accountability (to organisational mission) can be linked to triple loop learning as it implies reflecting on the learning mechanisms (employs learning-oriented evaluative approaches). The focus is not so much on outputs or outcomes but on "the process of continuous reflection on visions, strategies, actions and contexts that enable continual readjustments" [Guijt, 2010: 281]. Similarly, Ebrahim [2005: 80] argues: "Organisational learning is more likely if internal accountability to mission, rather than upward accountability to donors, guides NGO [non-governmental organisations] reporting". 
Table 2

Typical links between accountability and learning

\begin{tabular}{|l|l|l|}
\hline \multicolumn{1}{|c|}{ Type of accountability } & \multicolumn{1}{|c|}{ Type of learning } & \multicolumn{1}{|c|}{ Focus } \\
\hline $\begin{array}{l}\text { Upwards (to funders, governing } \\
\text { body) }\end{array}$ & No lesson learned & $\begin{array}{l}\text { Symbolic use of evaluation (to } \\
\text { legitimize decisions which have } \\
\text { already been made) }\end{array}$ \\
\hline & $\begin{array}{l}\text { Single loop } \\
\text { Are we doing things right? } \\
\text { according to the plan, within } \\
\text { the budget, complying with the } \\
\text { legal regulations etc. } \\
\text { Provides short-term solutions to } \\
\text { implementation problems and } \\
\text { deals with symptoms more than } \\
\text { root causes }\end{array}$ & $\begin{array}{l}\text { Focus on short-term, tangible, } \\
\text { intended effects of public in- } \\
\text { terventions (output oriented } \\
\text { evaluation) }\end{array}$ \\
\hline $\begin{array}{l}\text { Downwards (to those affected } \\
\text { by an initiative) }\end{array}$ & $\begin{array}{l}\text { Double loop } \\
\text { Are we doing the right things? } \\
\text { Results in strategy adjustments } \\
\text { and better mid- and long-term } \\
\text { course } \\
\text { Corrections following contex- } \\
\text { tual changes }\end{array}$ & $\begin{array}{l}\text { Focus on long-term, intended } \\
\text { and unintended effects; the } \\
\text { underlying causes and conse- } \\
\text { quences of a problem addressed } \\
\text { by an initiative (outcome ori- } \\
\text { ented evaluation) }\end{array}$ \\
\hline $\begin{array}{l}\text { Internal (to organisational } \\
\text { mission) }\end{array}$ & $\begin{array}{l}\text { Triple loop } \\
\text { How do we know that we are } \\
\text { doing right things? } \\
\text { Rethinking the core driving } \\
\text { values }\end{array}$ & $\begin{array}{l}\text { Focus on continuous improve- } \\
\text { ment (learning oriented evalu- } \\
\text { ation) }\end{array}$ \\
\hline
\end{tabular}

Source: own elaboration.

\section{Concluding remarks}

Bovens, Goodin and Schillemans [2014: 6] point to a certain minimum consensus regarding the understanding of the term "accountability", as they write: "The minimal conceptual consensus entails, first of all, that accountability is about providing answers: is about answerability towards others with a legitimate claim to demand an account". With such a broad understanding of the term "accountability", the function of accountability is not limited to verifying the compliance of the activities carried out with the plan and achieving the preconceived outcomes, but also tracking and documenting these departures from initial plans and explaining why objectives of the intervention have been modified. This is the situation when someone is responsible for things that happen and can give satisfactory reason for them. Using the words of Guijt [2010: 283]: "Being held accountable (...) means having "respond-ability".

In dynamic and complex environment which can be characterised by nonlinearity, emergence, adaptiveness, uncertainty and co-evolutionary processes 
(feedback-loops), it is hard to identify and control specific and measurable effects before proceeding with a public intervention. Taking the traditional, i.e. static and mechanical approach to the accountability function implies that any departure from the planned implementation, resignation from the attainment of certain indicators and seizing new opportunities would be considered as a failure. Following Henry Mintzberg's [2007] line of thinking the realised strategy should be a combination of deliberate as well as emergent strategy. Applying this to public interventions - while addressing complex societal problems one should read the context and adapt to what has been observed and learned in interaction with the complex and dynamic environment to increase the chances of actually reaching a goal of an intervention.

The prime example of such an approach is developmental evaluation, which is quite distinct from the more traditional formative and summative evaluations. While formative and summative approaches are concentrated on improving (in the first case) or assessing (in the latter case) an established initiative, developmental evaluation aims to supports innovation by collecting and analysing realtime data to inform and guide ongoing decision making as part of the design, development, and implementation process [Patton, 2011:36]. Thus, its purpose is to generate timely learning before there is a complete model of intervention to improve or assess [McDonald, 2016]. In this case, accountability entails "carefully, systematically, and thoroughly documenting these developmental shifts, making transparent the data on which changes are made, and tracking the implications of deviations from the original plan - both deviations in implementation and in emergent outcomes" [Patton, 2017: 15].

Obviously, this approach one can possibly assume in the case of internal accountability. When upwards accountability comes into question, the process of learning can be paralysed by strict rules and procedures for fairness and finance. Thus, what factors are crucial for facilitating learning in this case? First of all, vital are the relationships between the two parties of the accountability process: an actor and the so-called "accountability forum", which is a forum, in which the actor has an obligation to explain and justify his or her actions and which can pose questions, pass judgment, and the actor may suffer consequences [Bovens, 2007]. Important is the substantive focus of the accountability forum [Ebrahim, 2005; Schillemans, Smulders, 2016]. The focus of the long-term organisational goals foster learning, while short-term concentration on regularity and control is considered to be an obstacle. Secondly, this is interpersonal trust [Schillemans, Smulders, 2016]. Learning is more likely to take place when exchanges and contacts between the actor and the accountability forum are more informal than in the case of highly formal ones. It is believed that trust reduces the level of tension and brings a greater exchange of information. Thirdly, the attitude to failure is critical for organisational learning. Ebrahim [2005: 68] argues that: "Evaluations that reward success while punishing failure (e.g. through revocation of funds or additional conditions on funding) are unlikely to engender organisational learning because they encourage NGOs to exaggerate successes while discouraging them from revealing and closely scrutinizing their mistakes". Nevertheless, as a final 
remark it must be stressed that when accountability is to contribute to learning, clear performance expectations should be formulated, sufficient time allocated for evidence collection and analysis, as well as right engagement in a dialogue with those holding to account. Moreover, new models of evaluation have made it imperative to re-think the issue of accountability. The example is not only the aforementioned developmental evaluation but also increasingly more utilised empowerment evaluation [e.g. Wandersman et al., 2016]. Being responsive, tracking and documenting the process of change can also help to overcome the problem related to the demands of funding cycles and the need to deliver information when not all impacts of the intervention can be identified yet.

\section{References}

Argyris C., Schön D. A. (1996), Organisational Learning II: Theory, Method, and Practice, Addison-Wesley, Reading (Mass.).

Balcerak A. (2006), Symulacja we wspomaganiu i badaniu uczenia się organizacyjnego, Prace Naukowe Instytutu Organizacji i Zarzadzania Politechniki Wrocławskiej, 22, 80.

Bovens M. (2007), Analysing and assessing accountability: A conceptual framework, European Law Journal, 13, 4.

Bovens M., Goodin R., Schillemans T. (2014), Public accountability [in:] M. Bovens, R. Goodin, T. Schillemans (eds.), The Oxford Handbook of Public Accountability, Oxford University Press, Oxford.

Brandsen T., Vrielink M. O., Schillemans T., Van Hout E. (2011), Nonprofit organizations, democratization and new forms of accountability: A preliminary evaluation [in:] A. Ball, S. P. Osborne (eds.), Social Accounting and Public Management: Accountability for the Common Good, Routledge, London.

Cabrera D., Colosi L., Lobdell C. (2008), System thinking, Evaluation and Program Planning, 31,3 .

Ebrahim A. (2005), Accountability myopia: Losing sight of organisational learning, Nonprofit and Voluntary Sector Quarterly, 34, 1.

Engel P., Carlsson C. (2002), Enhancing learning through evaluation: Approaches, dilemmas and some possible ways forward, Paper commissioned by the Ministry of Foreign Affairs, Directorate-General for Development Cooperation, the Netherlands, to be presented at the 2002 EES Conference, Seville, 10-12 October 2002, http://www.dmeforpeace.org/wp-content/uploads/2017/06/Enhancing20learning20through20evaluations20paper2005-final.pdf [accessed: 10 September 2018].

Fiol C. M., Lyles M. (1985), Organisational learning, The Academy of Management Review, 10,4 .

Gamble J. (2008), A Developmental Evaluation Primer, Montreal: J. W. McConnell Family Foundation.

Guijt I. (2010), Accountability and learning [in:] J. Ubels, N.-A. Acquaye-Baddoo, A. Fowler (eds.), Capacity Development in Practice, Earthscan Publishing for a Sustainable Future, London-Washington. 
Lennie J., Tacchi J. (2014), Bridging the divide between upward accountability and learning-based approaches to development evaluation: Strategies for an enabling environment, Evaluation Journal of Australasia, 14, 1.

McDonald H. (2016), Developmental evaluation: A tool to support innovation, Evaluation Matters-He Take Tō Te Aromatawai, 2.

Mintzberg H. (2007), Tracking Strategies. Towards a General Theory of Strategy Formation, Oxford University Press, New York.

Najam, A. (1996). NGO Accountability: A Conceptual Framework, Development Policy Review, 14.

Olejniczak K., Rok J., Płoszaj A. (2012), Organizacyjne uczenie się i zarządzanie wiedzą przegląd koncepcji [in:] K. Olejniczak (red.), Organizacje uczące się. Model dla administracji publicznej, Wydawnictwo Naukowe Scholar, Warszawa.

Patton M. (2011), Developmental Evaluation. Applying Complexity Concepts to Enhance Innovation and Use, The Guilford Press, New York-London.

Patton M. (2017), Developmental evaluation [in:] J. Pokorski, Z. Popis, K. Herman-Pawłowska (eds.), Theory-Based Evaluation in Complex Environments, Polish Agency for Enterprise Development, Warsaw.

Regeer B., Wildt-Liesveld R. de, Mierlo B. van, Bunders J. (2016), Exploring ways to reconcile accountability and learning in the evaluation of niche experiments, Evaluation, 22, 1.

Schillemans T., Smulders R. (2016), Learning form accountability?! Whether, what, and when, Public Performance \& Management Review, 39, 1.

Senge P. M. (2012), Piata dyscyplina. Teoria i praktyka organizacji uczacych się, Wolters Kluwer, Warszawa.

Snowden D., Boone M. (2007), A leader's framework for decision making, Harvard Business Review (November).

Stame N. (2004), Theory-based evaluation and types of complexity, Evaluation, 10, 1.

Van der Knaap P. (2004), Theory-based evaluation and learning: Possibilities and challenges, Evaluation, 10, 1.

Wandersman A., Alia K., Cook B., Hsu L., Ramaswamy R. (2016), Evidence-based interventions are necessary but not sufficient for achieving outcomes in each setting in a complex world: Empowerment evaluation, getting to outcomes, and demonstrating accountability, American Journal of Evaluation, 37, 4. 